\title{
Amadeus
}

International Multidisciplinary Journal ISSN 2525-8281

DOI: 10.14295/aimj.v3i5.48

V.3, N. 5, p.35-50, Oct./2018 - ISSN 2525-8281

\section{Adenocarcinoma of Colon and Renal Carcinoma of Clear Synchronic Cells: A Case Report}

Morgana Tavares Dantas Sousa ${ }^{1}$, Antonio Taumaturgo Sampaio

Macêdo ${ }^{2}$

Marco Antônio Bezerra Rolim ${ }^{3}$, Roberto de Souza Mendonça, José Carlos Apolonio da Silva Ariovaldo Carvalho Neto ${ }^{6}$, Isabelita de Luna Batista, Hermes Melo Teixeira Batista

\begin{abstract}
This study reported the case of a patient with a diagnosis of colonic and renal synchronic tumors: Moderately differentiated adenocarcinoma of sigmoid and renal carcinoma of the synchronic clear cell variant in a 66-year-old female patient who were surgically resected in a single approach in an Oncology service in the interior of the State of Ceará, Brazil. For data collection, records of the medical record, interview with the patient and the surgeon responsible for the case, photographic record of the diagnostic methods to which the patient was submitted, and literature review were used. It followed all the ethical principles established by law 466/2012. From this study it was concluded that: a) the incidence of colorectal cancer and synchronic renal cell carcinoma ranges from 0.03 to $4.85 \%$ in the analyzed literature, $b$ ) risk factors for synchronic tumors include genetic and environmental factors; c) renal cell carcinoma is usually diagnosed by performing preoperative tests for staging of abdominal carcinomas. Still, large prospective studies are necessary to define the best therapeutic strategy, however, some authors have confirmed that simultaneous laparoscopic resection of both neoplasms is possible and presents low morbidity and mortality.
\end{abstract}

Keywords: synchronic tumor, colon cancer, renal cancer.

\footnotetext{
${ }^{1}$ Doctor from Estácio FMJ School of Medicine - Estácio FMJ

${ }^{2}$ Physiotherapist by the School of Medicine Estácio FMJ - Estácio FMJ E-mail: taumaturgomacedo@yahoo.com

${ }^{3}$ MSc Student in Health Sciences from FMABC.

${ }^{4}$ Medical Doctor, member of the Brazilian Society of Coloproctology

${ }^{5}$ Medical General Surgery Resident by Santa Casa de Misericórdia de Fortaleza. Post Graduating in Minimally Invasive Surgery and Robotics by Christus University.

${ }^{6}$ Medical Clinical Resident by FMUSP

${ }^{7}$ Nurse by URCA. Postgraduate in Clinical Nursing by UECE.

${ }^{8}$ MSc in Health Sciences by FMABC. PhD in Health Sciences by FMABC, Medical Doctor at HUJB in Cajazeiras, Professor of Medical Emergencies at Estácio (FMJ). Contact: hermesmelo@oi.com.br
} 


\section{Introduction}

Colon cancer is the third most frequent in the world and fourth in Brazil. A decline in its incidence and mortality has been identified in the last decade, probably due to improvements in diagnostic and therapeutic methods. Risk factors are divided into environmental and genetic factors. Among the environmental stresses are hypercaloric diet, high body mass index (BMI), red meat and fat intake, sedentary lifestyle, smoking and alcoholic intake, and as a general family history, inflammatory bowel diseases and hereditary syndromes such as polyposis hereditary non-polypoid colorectal tumor syndrome and the hamartomatous polyp syndromes (PeutzJeghers, Juvenile Polyposis Syndrome, Cowden).

Early detection is essential in the management of tumors and the diagnosis is based on biopsy during colonoscopy (rethosigmoidoscopy is insufficient, since the presence of synchronic tumors may reach 5\%) and staging is performed through physical examination, tomography of the chest, abdomen and pelvis, and CEA (carcinoembryonic antigen), using the TNM classification. (Brazilian Cancerology ociety, 2011).

For the Brazilian Society of Urology (2006), renal cancer is more prevalent in males (2: 1) between 50 and 70 years. Population screening for early detection is not justifiable because of its low prevalence. Incidental tumors have been more frequent due to improved imaging methods, combined with late and nonspecific symptom onset. Imaging includes simple radiography and excretory urography (UB), ultrasonography (US), computed tomography (CT), magnetic resonance imaging (MRI), nuclear medicine and arteriography. For staging, basically performed by CT and MRI, the TNM classification is the most used, but also available from the Robson system.

According to the definition of Campos et al. (2006), tumors are classified as synchronous when presenting simultaneously to the diagnosis or at the operative event, obviously excluding the possibility of contiguity lesions and metachronous tumors are those found in the follow-up of patients after surgical resection, excluding the possibility of undiagnosed lesion at the time of diagnosis (when it would be synchronous) or recurrence of the operated tumor.

The relevance of the study is in the discussion of the characteristics evidenced in the individual affected by the described tumor, which is a rare association that generates 
considerable controversy in the treatment and follow-up of the patient. It justifies being able to subsidize other scientific works within the area of cancer surgery.

From this explanation, this work raises the following problem: How is the patient diagnosed with colonic and renal synchronic neoplasms? The expected hypothesis is: Because colorectal cancer is more common and more diagnosed by population screening and because it is a rare association, the diagnosis of renal tumor is usually made in the preoperative evaluation or surgical procedure of the colorectal tumor.

\section{Methodology}

It is a study characterized as quantitative approach, as to the objectives as descriptive and as to the technical procedures as a case report. This is a descriptive study with a quantitative approach. This research characterizes the approach as quantitative. For Dalfovo, Lana and Silveira (2008), in the use of the quantitative approach everything can be measured in numbers, classified and analyzed using statistical techniques. The descriptive study demands from the researcher a series of information about what he wants to research and intends to describe the facts and phenomena of a certain reality (Triviños, 1987). The case reports are detailed descriptions of a case, important for presenting new and rare cases to the scientific community (Imip, 2006).

The data collection consisted in information obtained through a review of the medical record, an interview with the patient and the surgeon responsible for the case, a photographic record of the diagnostic methods to which the patient was submitted and a review of the literature. The data were confronted with studies present in some databases, seeking to correlate clinical aspects and treatment.

\section{Synchronous Neoplasms}

The incidence of two or more primary neoplasms in the same individual has progressively increased in the last decades. The occurrence of multiple primary neoplasms was first described by Billroth in 1877 and later defined by Warren and Gates in 1932 obeying the following criteria: each of the tumors must present a defined malignancy; one should rule out the likelihood of one metastasis being the other; and each should be distinct 
from the other. It is possible to classify as synchronous, those that have the simultaneous diagnosis, or metachronic, that appear in the same individual in different periods. (Hajdu, S., Hajdu, E., 1968; Lau et al., 2000).

If cancer is an aging phenomenon, longevity can result in an increasing number of several primary malignancies, especially renal and gastrointestinal neoplasms. Some patients may be at increased risk of multiple malignancies due to common carcinogenic exposure, genetic predisposition, side effect of treatment with chemotherapy or radiotherapy, endocrine factors or their interaction. The knowledge of this association can help the screening of a second cancer, since its presence may interfere in the choice of treatment and in the prognosis of the patient (Czene; Hemminki, 2002; Hajdu, Thomas, 1967; Lynch et al., 1997).

Colon cancer is the third most common malignant neoplasm in Brazil and the second most common cause of cancer death in the Western world. The risk of developing a tumor over the lifetime in the general population is about $5 \%$. Kidney cell carcinoma, responsible for about $85 \%$ of renal neoplasms, accounts for about $1 \%$ to $3 \%$ of all malignancies. In spite of the low occurrence of each malignancy, the incidence of renal cell carcinomas and synchronic colon adenocarcinoma is undoubtedly rare, finding in the literature a rate of $0.03 \%$ to $4.8 \%$ (Cobb et al., 2005 Czaplicki et al., 1986; Hajdu, S., Hajdu, E., 1968).

As in the case of these tumors the first to have diagnosis is usually colorectal and the renal is a finding in preoperative exams or surgery, the first will be better addressed in the next topic, and the latst one will have a brief review later.

\section{Colorectal cancer}

According to the International Agency for Research on Cancer (IARC) database Globocan (2002), colorectal cancer represents 550,000 new incidental cases and 278,000 deaths among men, and 473,000 new incidental cases and 255,000 deaths among women. In 2002 it accounted for $9.4 \%$ of the global cancer burden for both sexes and was most prevalent in North America, Australia, New Zealand, and parts of Europe (World Gastroentology Organization, 2007). In Brazil, the estimated number of new cases is 12,490 in men and 14,500 in women, which corresponds to an estimated risk of 13 new cases per 100,000 men and 15 cases per 100,000 women (Brazil, 2008). 
The type of test used for screening depends on the screening resources and dietary habits of the population. The Ministry of Health recommends screening for colon and rectum cancer using fecal occult blood screening, colonoscopy, or sigmoidoscopy in adults aged 5075 years. The risks and benefits vary according to the screening test (Brazil, 2010).

Anyone over the age of 50 is at moderate risk because the chance of colorectal cancer increases with age, and fecal occult blood screening (FOB) is the most commonly used test. High-risk patients are considered individuals with a personal history of adenomatous polyps, or colorectal, breast, endometrial or ovarian neoplasia, inflammatory bowel disease (IBD), family history of colorectal cancer or adenomatous polyps, and Hereditary Colorectal Neoplasm Syndromes. Colonoscopy is the ideal exam for follow-up of these patients and is performed with variable intervals, depending on the clinical history (Assis, 2011).

The annual FOB is recommended by all guidelines. If the result is positive, a colonoscopy is indicated. The disadvantages of the test are the low sensitivity in asymptomatic patients and advanced adenomas and the need for prolonged adherence to the program for 10 years to reduce mortality (Assis, 2011; World Gastroentology Organization, 2007).

In general, signs and symptoms appear in advanced stages of the disease and depend on the location and size of the tumor, and may be changes in bowel movements, blood loss, abdominal pain and general symptoms such as weight loss, anorexia, and asthenia. Tumors of the cecum, ascending colon, and proximal transverse colon can cause chronic hematic loss, with iron deficiency anemia and symptoms such as fatigue, angina pectoris and palpitations (Schwartz; Blanke; Pesko, 2004).

The most widely used staging system is the TNM, as defined by the American Joint Committee on Cancer, presented in the table below.

Table 1: Staging of colorectal cancer (TNM system)

\begin{tabular}{l|l|l|l}
\hline Stage & T & N & M \\
\hline Stage 0 & Tis & N0 & M0 \\
\hline Stage I & T1, T2 & N0 & M0 \\
\hline Stage II & T3, T4 & N0 & M0 \\
\hline Stage IIA & T3 & N0 & M0 \\
\hline Stage IIB & T4a & N0 & M0 \\
\hline Stage IIC & T4b & N0 & M0 \\
\hline Stage III & Any T & N1, N2 & M0 \\
\hline Stage IIIA & T1, & T2 & N1 \\
& T1 & N2a & M0 \\
\hline
\end{tabular}




\begin{tabular}{|c|c|c|c|}
\hline Stage IIIB & $\begin{array}{ll}\text { T3, } & \text { T4a } \\
\text { T2, T3 } & \\
\text { T1, T2 } & \\
\end{array}$ & $\begin{array}{l}\mathrm{N} 1 \\
\mathrm{~N} 2 \mathrm{a} \\
\mathrm{N} 2 \mathrm{~b}\end{array}$ & M0 \\
\hline Stage IIIC & $\begin{array}{l}\text { T4a } \\
\text { T3, T4a } \\
\text { T4b }\end{array}$ & $\begin{array}{l}\mathrm{N} 2 \mathrm{a} \\
\mathrm{N} 2 \mathrm{~b} \\
\mathrm{~N} 1, \mathrm{~N} 2\end{array}$ & M0 \\
\hline Stage IVA & Any T & Any N & M1a \\
\hline Stage IVB & Any $\mathrm{T}$ & Any N & M1b \\
\hline
\end{tabular}

Source: Adapted from: Sobin LH. Gospodarowicz. Wittekind C. Colon and rectum. In: TNM Classification of Malignant tumors. 7 th edition. Blackwell publishing ;. P. 100-105, 2010.

The therapeutic options available for the treatment of colorectal cancer include surgery, which is the main one; chemotherapy and radiotherapy, and new antiangiogenic drugs (Schwartz; Blanke; Pesko, 2004).

\section{Renal cancer}

Renal cell carcinomas are the seventh most common histological type of cancer in the Western world. Currently, most cases are incidentally discovered in imaging studies, performed for urological or non-urological reasons and there is a higher incidence in males, which accounts for about two-thirds of cases. The World Health Organization (WHO), according to the 2004 classification, recognizes several histological subtypes, the most frequent being clear cell renal carcinoma (CCRcc), papillary carcinoma (CCRp) and chromophobe (CCRcr). The set of these three subtypes accounts for more than $90 \%$ of all CCRs. (MUGLIA et al., 2015).

The clear cell variant is the most common, accounting for between $70 \%$ and $75 \%$ of all CCRs. In $95 \%$ of the cases it is sporadic, and in the remaining 5\%, associated with hereditary syndromes such as von Hippel-Lindau and tuberous sclerosis. This variant originates from the epithelium of proximal convoluted tubules (renal cortex) and presents predominantly expansive growth. Macroscopically, it is characterized by a solid, yellowish lesion with varying degrees of internal necrosis, hemorrhage and cystic degeneration. These findings are more common in large-volume, rapidly growing tumors. Tumor calcifications can also be found. Histologically, these lesions present clear cells due to their cytoplasmic content rich in lipids and glycogen. (Decastro and Mckiernan, 2008; Muglia et al., 2015). 


\section{Case Report}

A 66-year-old female patient, retired, catholic, divorced, from the city of São Paulo and from Assaré, State of Ceará, rural, literate, good information, anamnesis collected with the patient herself.

She was referred to the Oncology Service of the São Vicente de Paulo Hospital and Maternity with a clinical complaint of weight loss and that in routine exams anemia was evidenced in early 2014, refractory to oral iron supplementation. In August of that year, he underwent high digestive endoscopy without alterations and with positive urease test. He did a blind stool test that was positive. Shortly thereafter, he underwent a colonoscopy (image 1) showing an ulcer-infiltrated lesion in the sigmoid-descending transition, $45 \mathrm{~cm}$ from the anal margin, which was biopsied and showed to be moderately differentiated adenocarcinoma.

Image 1 - Diagnostic colonoscopy
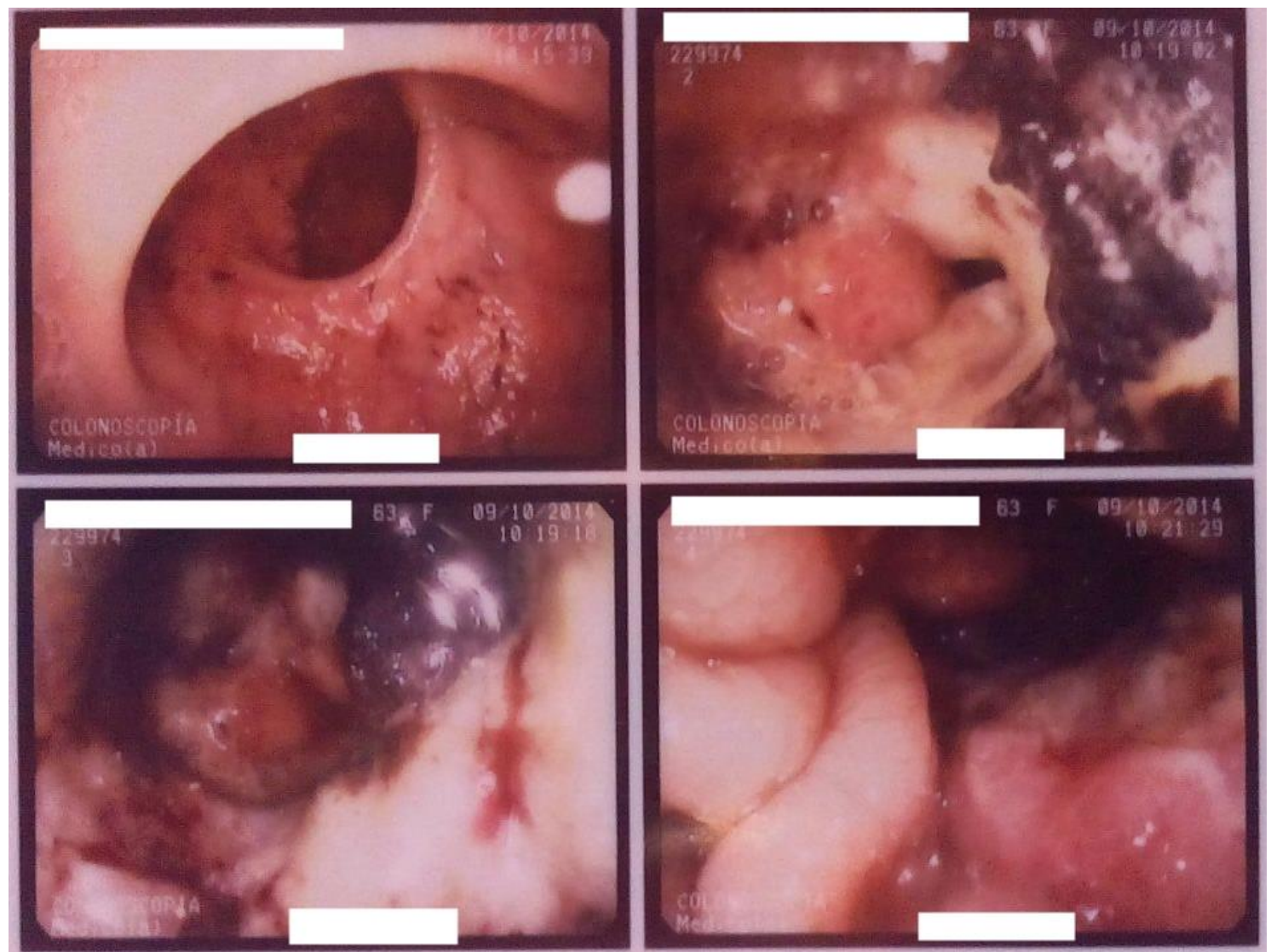

Source: Case Patient (2015) 
Has a medical history of hypertension for more than 10 years in treatment (in the use of losartan and hydrochlorothiazide); refers to measles at 2 years of age, which left sequelae of left lower limb force deficit; performed cataract surgery in 2010; allergy to vaginal ointments (SIC), denies previous hospitalizations. He reports that the older brother died 5 years ago due to cancer, not knowing the origin of the neoplasia. There are six more siblings without reports of neoplasms until then. Parents deceased by unknown causes.

In preoperative evaluation, computed tomography (CT) of the upper abdomen (image 2) showed a heterogeneous solid mass with poorly defined contours, liquefied / necrotic center in the cortex of the right upper pole of the right kidney $(5,2 \mathrm{~cm} \times 5,0 \mathrm{~cm} \mathrm{x} 4,6 \mathrm{~cm})$; Chest $\mathrm{CT}$ within normal range; requested preoperative carcinoembryonic antigen (CEA) equal to $2.33 \mathrm{ng} / \mathrm{ml}$.

Image 2 - Computed tomography of total preoperative abdomen

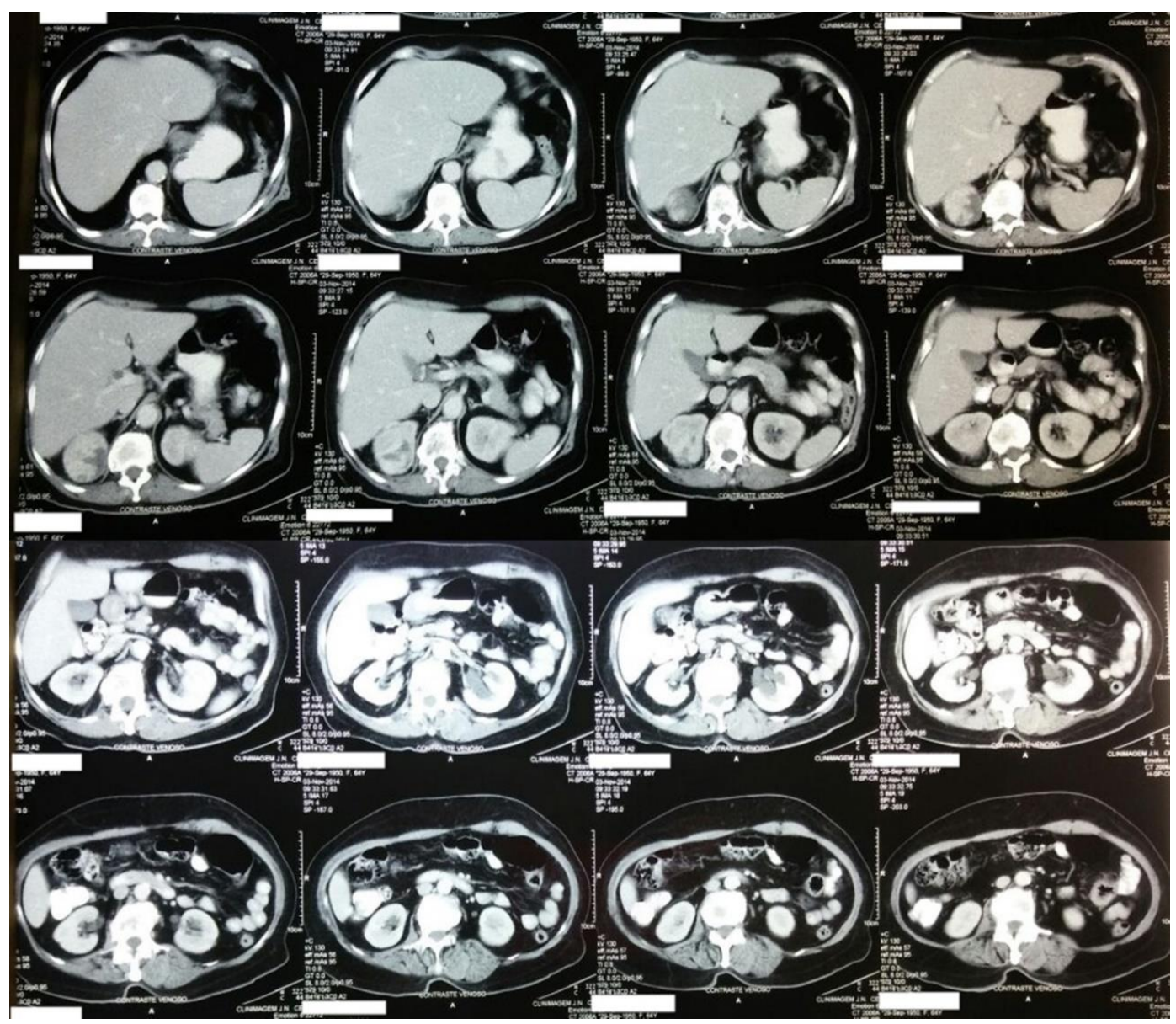

Source: Case Patient (2015) 
In January 2015, the patient underwent right radical nephrectomy and retosigmoidectomy with retroperitoneal lymphadenectomy with primary anastomosis, evolving without intercurrences in the postoperative period.

Histopathological study revealed a sigmoid tumor showing a moderately differentiated invasive adenocarcinoma measuring $3.4 \mathrm{~cm}$ in its major axis, infiltrating the entire thickness of the wall and extending to the pericolic fat by $0.5 \mathrm{~cm}$ of thickness; present lymphatic vascular invasion; undetected vascular and perineural invasion. Surgical margins free of neoplasia. Adenocarcinoma metastasis compromising 3 of 16 lymph nodes examined with capsular transposition.

Absence of undifferentiated neoplastic component (Budding). Pathological staging of the sigmoid T3N2 (image 3). Right kidney tumor evidencing renal cell carcinoma of the clear cell variant measuring $4.5 \mathrm{~cm}$ on its largest axis, infiltrating renal capsule; mitotic index $0 / 10$ CGA; absent lymphatic, blood and perineural invasion; presence of focal necrosis; renal neoplasia-free renal structures, free margins, remaining normal renal parenchyma (Image 4).

Image 3 - Biopsy of the colon

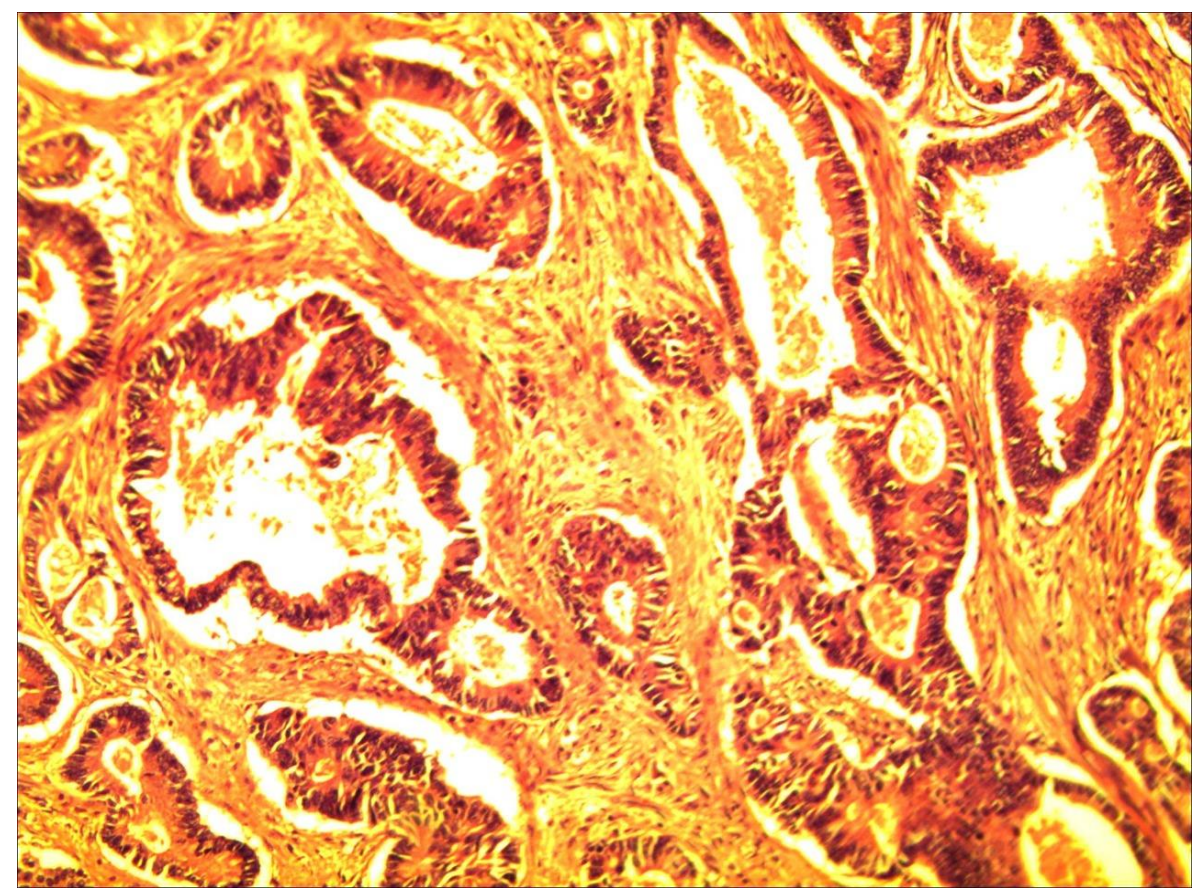

Source: São Vicente de Paulo Maternity Hospital (2015) 
Image 4 - Biopsy of the right kidney

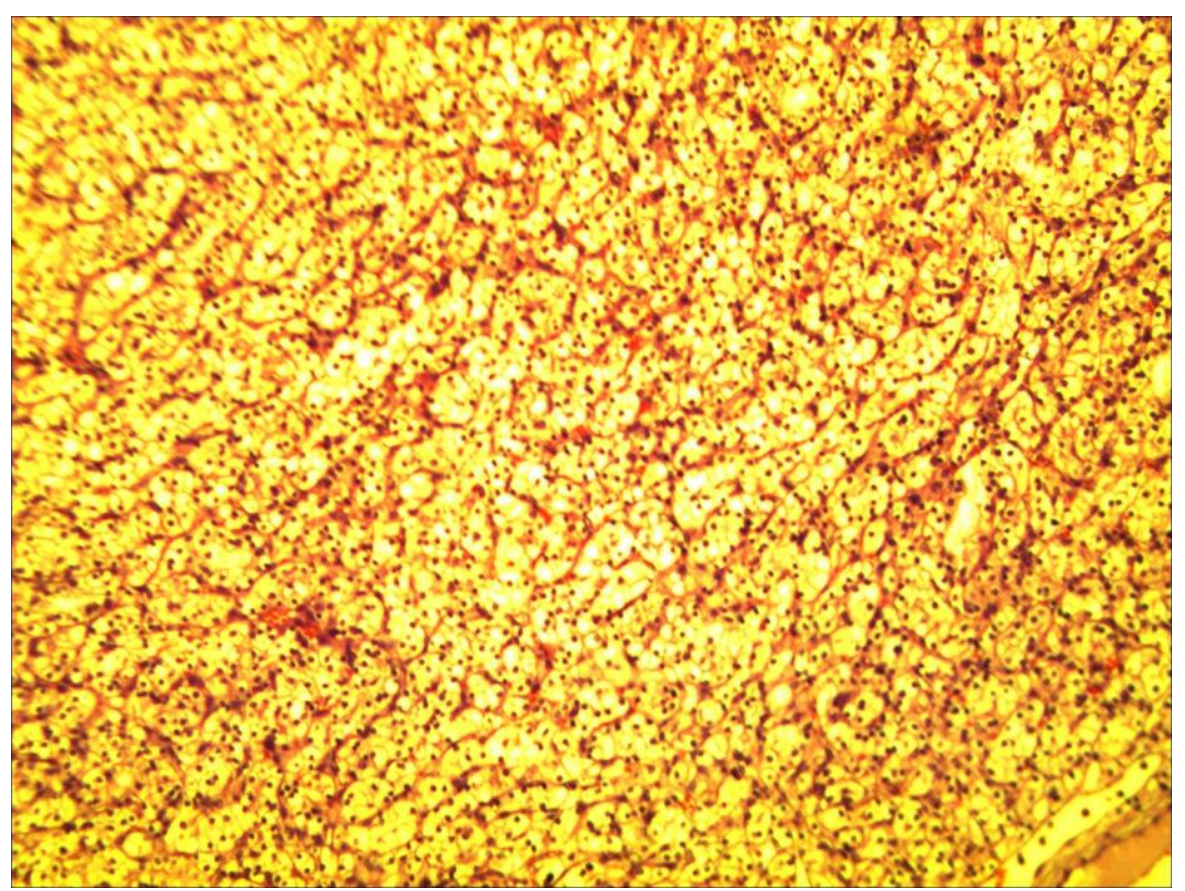

Source: São Vicente de Paulo Maternity Hospital (2015)

Forwarded to clinical oncology in March 2015, with CEA $2.7 \mathrm{ng} / \mathrm{ml}$, and chemotherapy with six cycles of Capecitabine and Oxiliplatin was indicated, concluding treatment four months later.

To date, the patient is being followed up every three months in the oncology outpatient clinic with no signs of relapse in abdominal CT (Image 5) or colonoscopy (Image 6) and CEA equal to 2.9 . 
Image 5 - Computed Tomography of the abdomen 07 months after the surgery

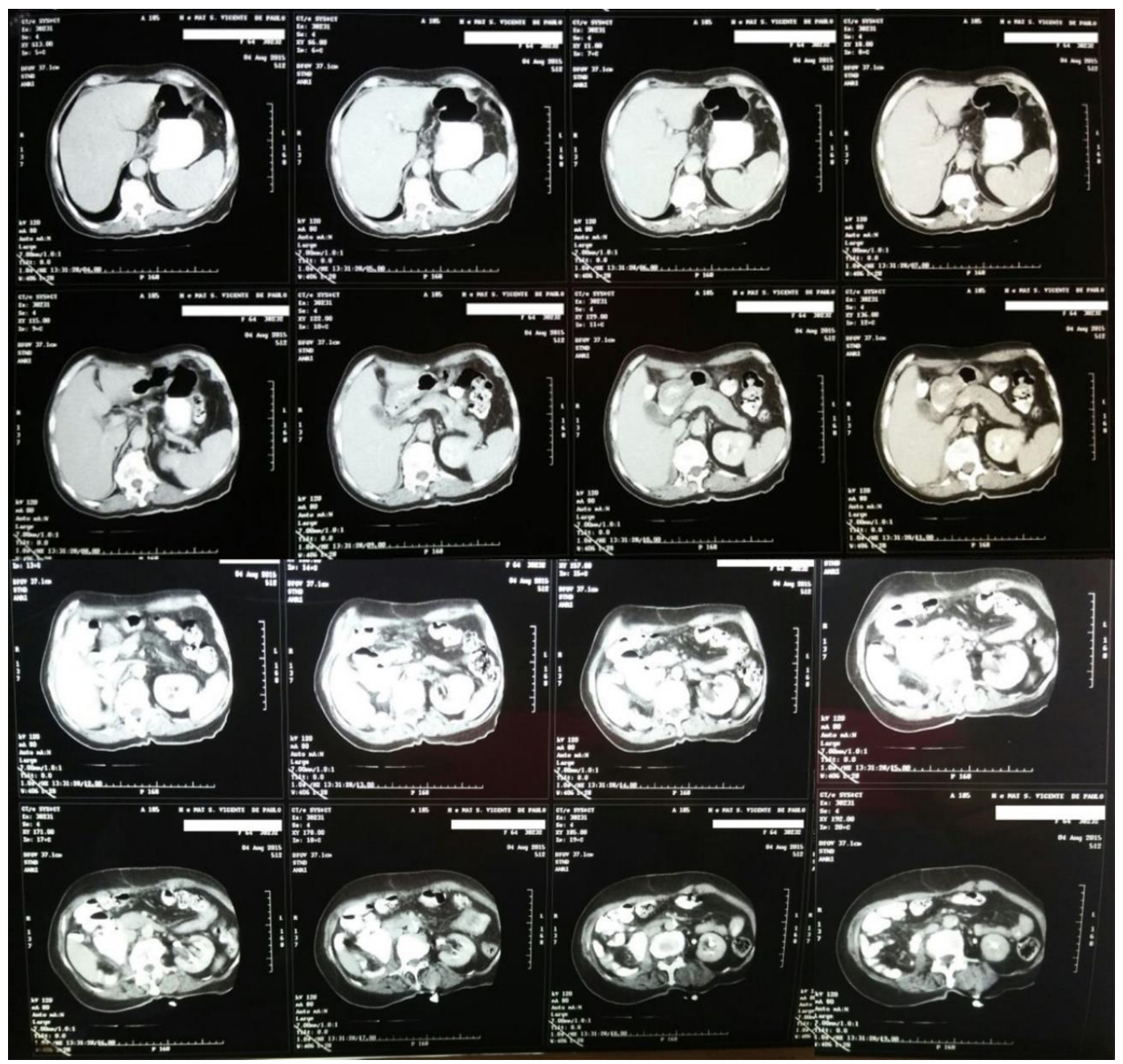

Source: Case Patient (2015)

Image 6 - Colonoscopy 02 years after the surgery
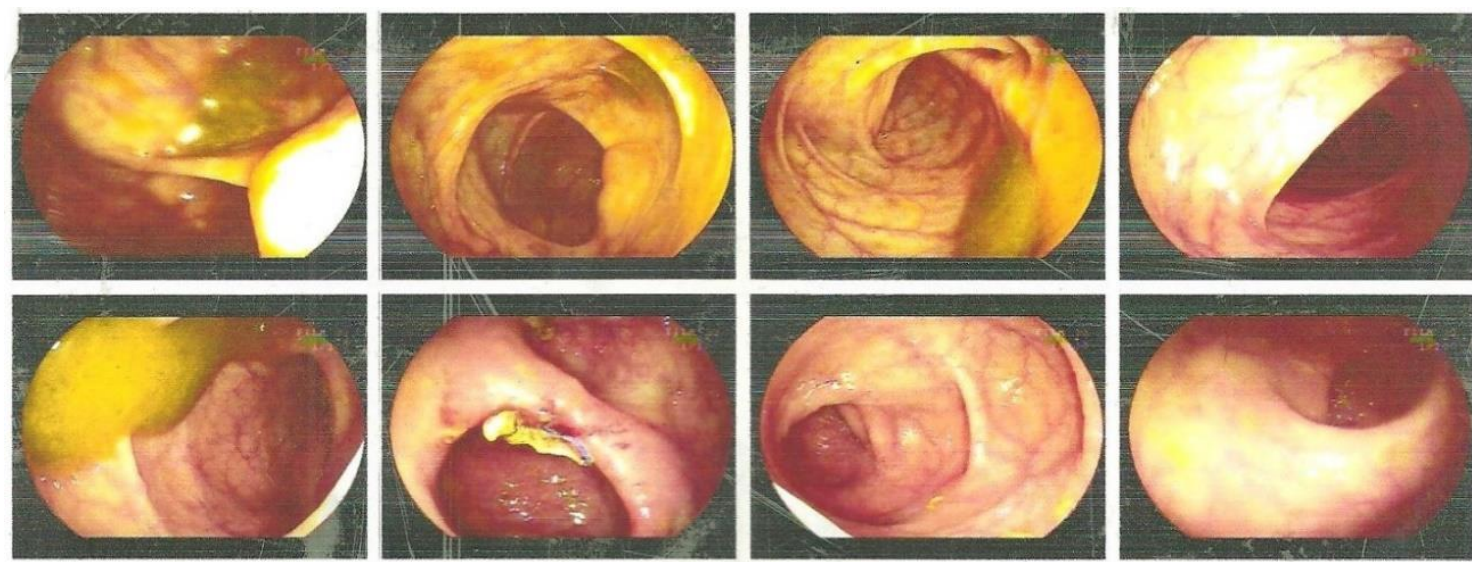

Source: Case Patient (2015) 


\section{Discussion}

The occurrence of synchronic neoplasias is already well defined in the literature. As shown by Czene and Hemminki (2002) renal cell carcinoma (CCR) is associated with a higher risk of developing another primary neoplasm, such as colorectal cancer, bladder cancer, prostate cancer and lung cancer, which justifies further investigation in patients first diagnosed with CRC. Clear renal cell carcinoma is the most common subtype of CRC and its median survival varies according to the age of presentation and tumor stage (Czene; Hemminki, 2002).

The association of other malignant primary tumors during nephrectomy with renal cell carcinoma is an independent risk factor for overall survival after surgery. (Czaplicki et al., 1986). Although it is difficult to evaluate, it is estimated that the incidence of colorectal cancer and synchronic RCC is $0.03-0.5 \%$. (Capra et al., 2003). However, there are variable incidences in other studies, reaching a maximum of $4.85 \%$ as evidenced by Halaque et al. (2000).

In autopsy studies conducted by Hajdu and Thomas (1967) and Hajdu, S. and Hajdu, E. (1968), colon cancer appears to be associated with renal cell carcinoma with an incidence of $4 \%$ or $9 \%$, respectively. In the latter, the incidence of colon cancer and synchronous renal tumors is $0.1 \%$. Asymptomatic renal carcinoma is found in $0.03-0.5 \%$ of patients with colorectal carcinoma (Capra, F. et al., 2003). Renal metastases from a colon tumor are eventually observed in cases of advanced disease. Colonic metastases from a renal cell carcinoma are also possible, but it is a much rarer event. One should be aware of the possibility of being in the presence of a case of a synchronous tumor colon and kidney in the preoperative evaluation. (Aoroso et al., 1999; Aksu et al., 2003).

The Risk factors for synchronic tumors include genetic and environmental factors, which may act individually and in combination, and are represented, as in many other malignancies, by tobacco, pollution, ultraviolet light, chemotherapy and therapeutic radiotherapy, endocrine factors, as well as factors unknown. As for the genetic factors, Lynch II Syndrome was described. This is the association of hereditary non-polyposis colorectal cancer with malignant tumors of other viscera, including the kidney (Lynch et al., 1997). In our case, the patient was not able to report information that classified her as high risk, 
according to the Amsterdam criteria, to present the syndrome, not justifying further genetic research.

The CCR is usually diagnosed with preoperative tests for staging of abdominal carcinomas, as occurred in the case described above. This shows us the valuable contribution of the imaging tests to diagnose synchronic tumors, especially the asymptomatic tumors.

There are controversies in the treatment of tumors, whether they will be treated at the same time or separately. As in most cases reported in the literature, there was simultaneous resection of both malignancies. Both were radical surgical gestures. According to Cullinane et al. (2001) combined surgery has a lower risk of morbidity. The usual surgical approach is by open laparotomy, preferred by surgeons. In contrast to conventional open surgery, the laparoscopic approach is associated with faster postoperative recovery periods and lower rates of postoperative morbidity (Cobb et al., 2005; Leung et al., 2004, Raghuram, Godbole, Dasgupta, 2005), which can often allow an early onset of adjuvant therapy. However, some authors have shown that simultaneous laparoscopic resection of both neoplasms is possible and presents low morbidity and mortality (Czene; Hemminki, 2002).

However, large prospective studies are needed to define the best therapeutic strategy. After a nephrectomy for $\mathrm{CRC}$, in a group of patients with normal renal function preoperatively more than $20 \%$ may develop chronic renal failure over time (Lau et al., 2000).

The accompanying schedule is also controversial in the literature. Our patient had a quarterly follow-up in the first year of follow-up and showed no signs of recurrence or metastasis.

\section{Final Considerations}

It is concluded that the incidence of colorectal cancer and synchronic renal cell carcinoma ranges from 0.03 to $4.85 \%$ in the analyzed literature and is therefore a rare condition. In addition, the risk factors for synchronic neoplasms may be genetic and environmental, with an important prominence for a positive family history of synchronic neoplasms, inflammatory bowel diseases and hereditary syndromes such as familial adenomatous polyposis, non-polypoid hereditary colorectal tumor syndrome, and syndromes 
with hamartomatous polyps. The patient in question was not able to report information that classified her as high risk.

Regarding the diagnosis, renal cell carcinomas are usually diagnosed by performing preoperative tests for staging of abdominal carcinomas or in the surgical procedure, since abdominal tumors are more frequent in the general population and have an earlier diagnosis.

Further large prospective studies are still needed to define the best surgical therapeutic strategy, with open laparotomy being preferred by some surgeons. However, some authors have shown that simultaneous laparoscopic resection of both neoplasms is possible and presents low morbidity and zero mortality. Still, the ideal is for the professional to perform the one that he thinks is more qualified to the process.

\section{References}

Amoroso, A. et al. (1999). A infrequente associação de malignidades renais e do cólon síncronas, EurMedRevPharmacolSci, (3), 3 p.111-114.

Aksu, G. et al. (2003). O cancro do cólon com isolado metástase para o rim no momento da inicial diagnóstico, Int J CancerGastrointest, (34), .2-3, p. 73-77.

Assis, R.V. B. F. (2011). Rastreamento e Vigilância do Câncer Colorretal: Guidelines Mundiais. GED gastroenterol. endosc.dig. (30) 2, p.62-74.

Brasil. Conselho Nacional de Saúde. (2012). Resolução no 466, Diário Oficial da União.

. Ministério da Saúde. Brasil. Instituto Nacional do Câncer (INCa). Estimativa 2008: Incidência de câncer no Brasil [online]. Retrieved in:

〈http://www.inca.gov.br/estimativa/2008/index.asp?link=conteudo view.asp\&id=5>.

Ministério da Saúde. (2010). Secretaria de Atenção à Saúde. Departamento de Atenção Básica. RASTREAMENTO Série A. Normas e Manuais Técnicos Cadernos de Atenção Primária, n. 29. - Brasília: Ministério da Saúde.

Campos, F.G. et al. (2006). Tumores colorretais metacrônicos. Coloproct; (26) supl.1: p.33.

Capra, F. et al. (2003). Synchronouscolorectaland renal carcinomas. Is it a definiteclinicalentity? Chirltal, (55) p. 903-906.

Cobb et al. (2005). Laparoscopicadrenalectomy for malignancy. Am J Surg, n. 189, p.405411. 
Cullinane, C.A. et al. (2001). Asymptomatic renal neoplasms in the rectal cancer patient. AmSurg (67), p. 1162-4.

Czaplicki et al. (1986). Resultados tardios do tratamento cirúrgico de carcinoma de células claras renal. IntUrolNephrol, (18)1, p. 37-43.

Czene, K.; Hemminki, K. (2002). Kidney cancer in the Swedish Family Cancer Database: familial risks and second primary malignancies. Kidney Int, (61), p. 1806-13.

Dalfovo, Michael Samir; Lana, Rogério Adilson; Silveira, Amélia. (2008). Métodos quantitativos e qualitativos: um resgate teórico. Revista Interdisciplinar Científica Aplicada, Blumenau, (2),4 p.01- 13, Sem II.

Decastro, G. J.; MCkiernan, J.M. (2008). Epidemiology, clinical staging, and presentation of renal cell carcinoma. Urol Clin North Am.; (35), p. 581-92.

Hajdu, S.I.; Hajdu, E. O. (1968). Múltiplos tumores malignos primários, J AmGeriatr Soe, (16)1, p. 16-26.

Hajdu, S.I.; Thomas, A.G. (1967). Carcinoma de células renais na autópsia, J Urol, (97)6, p. 978-982.

Halaque, M. et al. (2000). Synchronouscolorectal e carcinomas renal: a clínica notável entidade. Relatório de cinco casos, DisColonrecto, (43)9, p. 1314-1315.

Intituto Materno Infantil Professor Fernando Figueira - IMIP. Escola Pernambucana de Medicina e Escola Pernambucana de Saúde. Desenho do estudo I. Retrieved in: <http://www.imip.org.br>.

Lau et al. (2000). Comparação Matched de nefrectomia radical vs cirurgia em pacientes com carcinoma de células renais unilateral e um rim contralateral normal, poupadora de néfrons. MayoClinProc, (75), p. 1236 - 42.

Leung, K.L. et al. (2004). Laparoscopicresectionofrectosigmoid carcinoma: a prospectiverandomisedtrial. Lancet.; (363), p.1187-1192.

Lynch et al. (1997). Etiologia, história natural, gestão e genética molecular de câncer colorretal hereditário sem polipose (Lynch síndromes): implicações de aconselhamento genético, Cancro EpidemiolBiomarkersPrev, (6) 12, p. 987-991.

Muglia, V. F; Prando, A. (2015). Carcinoma de células renais: classificação histológica e correlação com métodos de imagem. Radiol Bras.; (48) 3, p. 166-174.

Raghuram, S.; Godbole, H. C., Dasgupta, P. (2005). Laparoscopicnephrectomy: the new gold standard? Int J ClinPract; (59) p. 128-129.

Schwartz, R.; Blanke, C.; Pesko, L. (2004). Target therapies in the treatment of colorectal cancer: what managed care needs to know. J Manag Care Pharm; (10) 5, Suppl B: S2-13. 
Sociedade Brasileira de Cancerologia. (2011). Diretrizes Clínicas na Saúde Complementar. Associação Médica Brasileira e Agência Nacional de Saúde Complementar. Câncer de Cólon: Tratamento Quimioterápico.

Sociedade Brasileira de Urologia. (2006). Projeto Diretrizes. Associação Médica Brasileira e Conselho Federal de Medicina. Câncer Renal: Diagnóstico e Estadiamento.

Triviños, A. N. S. (1987).Introdução à pesquisa em ciências sociais: a pesquisa qualitativa em educação. São Paulo: Atlas.

World Gastroenterology Organisation. (2007). Practice Guidelines: Triagem do câncer colorretal.

\section{How to cite this article (APA format):}

Sousa, Morgana Tavares Dantas; Macêdo, Antonio Taumaturgo Sampaio; Rolim, Marco Antônio Bezerra, Mendonça, Roberto de Souza; Silva, José Carlos Apolonio da; Carvalho Neto, Ariovaldo, Batista, Isabelita de Luna; Batista, Hermes Melo Teixeira (2018). Adenocarcinoma of Colon and Renal Carcinoma of Clear Synchronic Cells: A Case Report Am. In. Mult. J., Oct. (5) 3, 35-50.

Received: 07/30/2018.

Accepted: 08/10/2018. 